\title{
Corporate Citizenship: Structuring the Research Field
}

\author{
Alexander Kruggel ${ }^{1}$, Victor Tiberius ${ }^{1, *}$ a and Manuela Fabro ${ }^{2}$ \\ 1 Faculty of Economics and Social Sciences, University of Potsdam, 14482 Potsdam, Germany; \\ akruggel@uni-potsdam.de \\ 2 Institute for Philosophy, History of Literature, Science \& Technology, Technical University Berlin, \\ 10623 Berlin, Germany; manuela.fabro@yahoo.de \\ * Correspondence: tiberius@uni-potsdam.de
}

Received: 3 June 2020; Accepted: 24 June 2020; Published: 30 June 2020

\begin{abstract}
Corporate citizenship, which is firms' societal engagement beyond customer and shareholder interests, is a prominent topic in management practice and has led to extensive research. This increased interest resulted in a complex and fragmented scholarly literature. In order to structure and map the field quantitatively, we conducted a temporal analysis of publications and citations, an analysis of the productivity of involved disciplines, an analysis of the productivity of publication forms including journal impact factors, an author productivity and citation analysis, a co-author analysis, an article citation analysis, an article co-citation analysis, and a keyword co-occurrence analysis. Results of these bibliometric analyses show that corporate citizenship research seems to have been in a phase of stagnation since 2014 and shows a rather low degree of interdisciplinarity. Papers are predominantly published in high impact journals. Authors show little collaboration with other researchers. Current research relates to other business ethics topics, addresses philosophical foundations, and starts to relate to human resource management and organization studies.
\end{abstract}

Keywords: bibliometric analysis; corporate citizenship; corporate social responsibility; CSR

\section{Introduction}

First coined in 1969 [1] and gaining momentum around 2004 [2-9], corporate citizenship (CC) describes the civic behavior of companies. When a company acts like a good citizen, it goes far beyond shareholder interests and the interests of the stakeholders close to the company by addressing society as a whole. It is known that companies such as Bosch or Siemens were already socially involved in the 1920s [10]. In the United States, this topic became more important in the 1980s [11]. The creation of the Ron Brown Corporate Citizenship Award by US President Bill Clinton increased public awareness of the concept [12,13].

With increasing importance in practice, science has become more concerned with the topic and has produced a large number of publications over the past 50 years, creating a confusing research landscape. Traditionally, in order to structure such a topic, literature reviews are used [14]. In contrast to this qualitative approach, with today's technical possibilities, bibliometric analyses are also available as a quantitative and thus objective method. The number of publications and, in particular, citations is considered to provide information about the impact of research [15].

Against this background, we aim to map the corporate citizenship literature bibliometrically. Specifically, we employ a temporal analysis of publications and citations, analyze the productivity of involved disciplines, analyze the distribution of publication forms, and analyze the impact factors of journals that have published on corporate citizenship. We also conduct an author productivity and citation analysis, an author co-citation analysis, an article citation analysis, an article co-citation analysis, and a keyword co-occurrence analysis. 
Our analysis complements recent bibliometric analyses on the related and popular [16] concept of corporate social responsibility (CSR) [17-23] as well as recent CSR literature reviews [13], which partly focus on interfaces with other fields [24-27]. The relationship between corporate citizenship and CSR seems to be rather unclear [28]. For example, some scholars emphasize differences in their basic elements but suggest that they are basically similar approaches [29]. According to Camilleri [30], CSR is characterized by the businesses' voluntary societal engagement. However, he refers to such behavior as corporate citizenship as well, which suggests an overlapping definition of both concepts. Van Luijk [31] sees CSR as a concept not natural to firms, therefore provoking a conflict with a firm's original purpose, i.e., maximizing profits by satisfying customer demands, whereas corporate citizenship stresses that firms are a natural part of society. Corporate citizenship can also be seen as a sub-term of CSR [32,33]) with CSR representing a holistic concept of an all-embracing responsibility that addresses every aspect of a firm such as fairness towards suppliers [34] or striving for employee wellbeing [35] by, for example, investing in their intellectual capital [36]. Conversely, corporate citizenship is limited to "charitable donations and other forms of corporate philanthropy undertaken in the local community" [37]. Finally, corporate citizenship can be interpreted as CSR's designated successor [16] as corporate citizenship "was originally meant to emphasize, broaden and redirect specific dimensions of CSR" [38] (pp. 241]. Either way, despite the overlaps between corporate citizenship and CSR, corporate citizenship seems to have gained the status of a research field in its own right, which makes a bibliometric analysis relevant.

However, research on both concepts-corporate social responsibility and corporate citizenship-largely differs from a bibliometric point of view. While a title search for corporate social responsibility leads to more than 5500 publications, for corporate citizenship only 144 articles can be found (April 2020). Both research streams continue to produce publications.

The paper is structured as follows: starting with the methodology section, we describe in detail the employed bibliometric methods, specifically their function and applicability for the corporate citizenship research field. The usage of different bibliometric methods ensures broader and more detailed results for a research topic with a wide range of interconnected sub-fields. After presenting the results of the analyses, we highlight key interpretations.

Our research contributes to the corporate citizenship, and indirectly, to the CSR literatures by adding a quantitative and objective perspective on published research and therefore mapping the research field.

\section{Methodology}

\subsection{Bibliometric Methods}

The formerly used term "statistical bibliography" [39] makes it clear that bibliometrics objectively analyze publications in a defined research field using statistical methods [40-43]. Citations, the main measure in bibliometrics, are considered to represent scientific relevance and impact [43-48]. Bibliometric analyses are also established in the field of business ethics [49-57] and sustainability [58-68].

To map the research landscape of corporate citizenship, we employ several specific bibliometric analyses. We start with a temporal analysis to see how the numbers of publications and citations evolved over time. We then analyze which disciplines are involved in corporate citizenship research and which proportions they represent, to get a better understanding of the interdisciplinarity of the field. Next, analysis of the productivity of publications involves using the proportion of different publication forms and, for journals, their impact factors to discover if the impact of single publications is related to the overall journal impact factors. The impact factor of a journal indicates how often on average a paper from the journal in question has been cited. The higher the impact factor, the more relevant a journal can be viewed. With this analysis, we can figure out if corporate citizenship research is seen as publishable in top-tier journals. Then, we focus on authors and assess their productivity and impact. This is to provide an overview of the size and subject-specific diversity of the research community [69]. Additionally, the co-author citation analysis reveals the general degree of cooperation 
in the corporate citizenship field and identifies specific author communities. A closer look at the published articles involves citation and co-citation analysis. In the analysis of the most cited, i.e., most impactful, papers, we rank the articles by the average number of citations per year in order not to favor older publications. The article co-citation analysis examines how often articles were cited in other articles [39]. Strong co-citation links show the intellectual origins of individual authors [70] and suggest similarities regarding specific topics within the corporate citizenship field [43,71]. This science mapping method allows us to identify research clusters. Finally, we conduct keyword co-occurrence analysis, which examines which keywords below the abstracts are mentioned most frequently. This shows which research field and which core topics publications can be assigned to, which allows conclusions to be drawn about past, ongoing, and emerging research. For the bibliographic analyses, we used the software VOSViewer, which processes and maps bibliometric data visually and therefore supports the interpretation of the results [72-74].

\subsection{Data Collection}

The Web of Science Core Collection was used to collect the data for our analyses, since the records in this database are considered to be comprehensive and cross-disciplinary $[57,75]$. The search was conducted on 8 December 2019 and included the exact pair of terms "corporate citizenship" in the title to ensure that the data set only contained publications that deal with corporate citizenship essentially and not only marginally. The language filter was set exclusively to English as an international academic language. A time filter was not set. To ensure that only high-quality publications were taken into account, a quality threshold was applied [76] by manually sorting out all articles that were published in journals assigned to the 3rd and 4th quartile according to the Scimago Journal Rank (SJR). We preferred the SJR over the Journal Citation Reports (JCR) Journal Impact Factor (JIF) quartiles as the former contains more journals. As a result, the data set contains 104 publications.

\section{Results}

\subsection{Temporal Analysis of Publications and Citations}

Based on our data set, the first publication on the subject of corporate citizenship was published in 1969. Up until the year of 2003, one to two papers were occasionally published at irregular intervals. Up until and including 2003, only 13 (10.58\%) works were published. In comparison to previous years, in 2004 the number of publications increased noticeably to eight. From here on, the number of publications fluctuates. The years 2006, 2015, 2016, 2018, and 2019 are each marked with one to three publications. The strongest years were 2004, 2010, 2011, and 2017, with at least eight to eleven publications. In the middle range are the years 2005, 2007, 2008, 2009, 2012, and 2014, with four to seven publications. Figure 1 shows the chronological course of the publications. Those years that do not appear on the timeline in the illustration have no publications. This is particularly true for the long period between 1971 and 1994. From a chronological point of view, it shows that the first 35 years of corporate citizenship research were characterized by few publications, which changed in 2004. Even if more has been published since that year, a certain instability can still be seen as there are always periods with little publication activity. It remains to be seen if the COVID-19 crisis [77] will have an effect on the further development. 


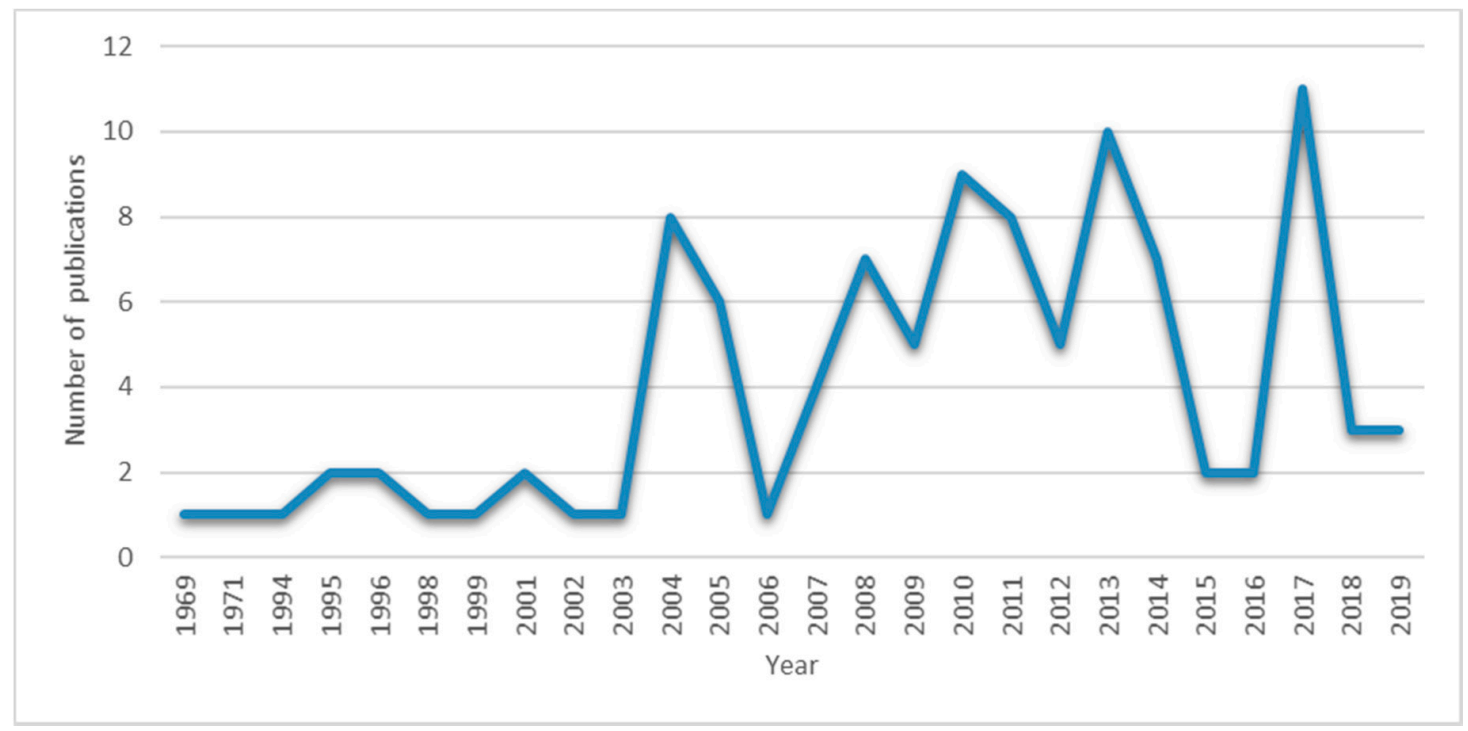

Figure 1. Publications per year.

With regards to the number of citations of the respective years, it is striking that a similar picture emerges here. A low-citation phase can be stated from 1969 to 1997. Figure 2 shows the sum of the citations (y-axis) in relation to the respective year ( $\mathrm{x}$-axis). For reasons of legibility, the illustration does not begin before 1985. As of 1998, the number of citations increased for the first time, reaching a double-digit figure for $12 / 15$ in 2003/2004. After this second phase of the initially slow increase, a more rapid increase in citations can be observed from 2005 (26 citations). Ultimately, a peak of 428 was reached in 2018. What is striking here is the exponential increase in citations since approx. 2005, which has generated a relatively constant increase in the number of citations. Even if slight drops (e.g., 2016, 2019) can be seen, they ultimately do not detract from the rising overall picture.

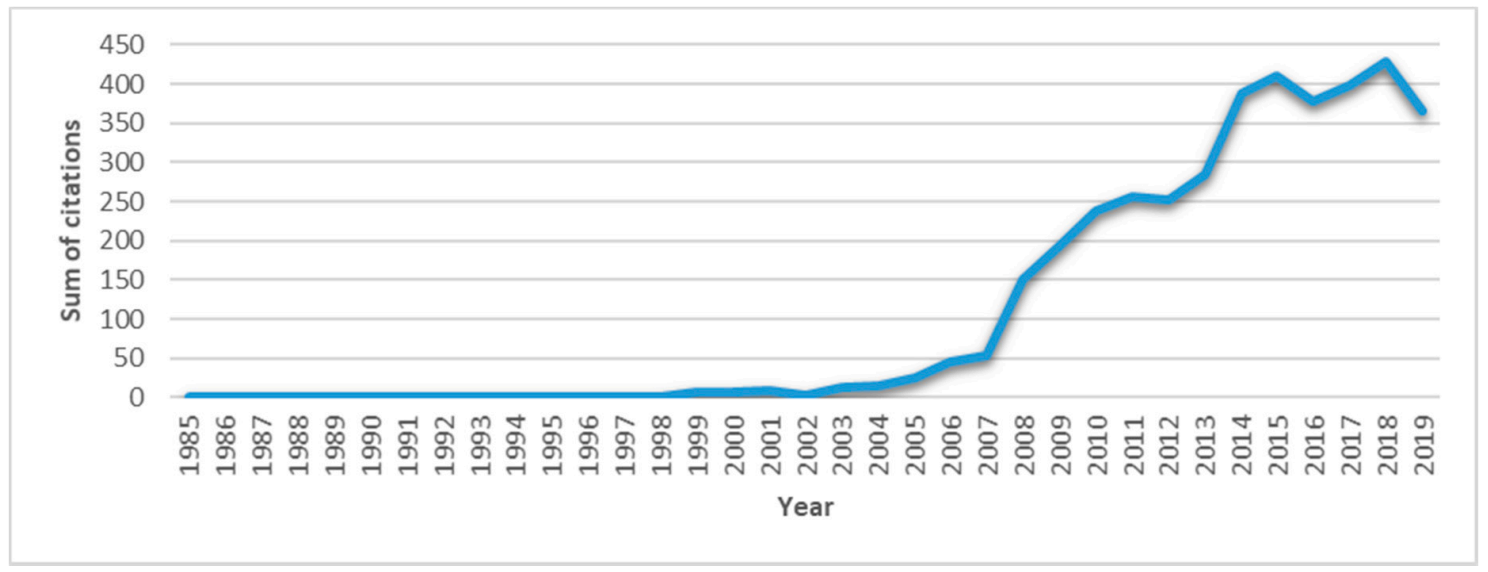

Figure 2. Citations per year.

\subsection{Productivity of Disciplines}

Corporate citizenship is researched in several scientific disciplines. Most publications can be found in the business category with $65(62.5 \%)$ publications. This is followed by the subject area ethics with $35(33.65 \%)$ and by management with $24(23.01 \%)$ publications (Table 1$)$. The total exceeds 104 publications $(100 \%)$ because some publications are assigned to more than one discipline, just as the field of business ethics can generally be assigned to both business and ethics. 
Table 1. Top five disciplines.

\begin{tabular}{ccc}
\hline Disciplines & Number of Publications & In \% \\
\hline Business & 65 & 62.5 \\
Ethics & 35 & 33.65 \\
Management & 24 & 23.08 \\
Political Science & 6 & 5.77 \\
Environmental Studies & 5 & 4.81 \\
\hline
\end{tabular}

\subsection{Productivity of Publication Forms}

Of the 104 publications, 79 (75.92\%) are journal articles; 22 (21.15\%) are book chapters, books or book reviews; $10(9.62 \%)$ are editorial material; three $(2,89 \%)$ are reviews; and one $(0.92 \%)$ is a press release. Journal articles clearly constitute the majority.

A review of the publication forms (Table 2) shows that $22(21.15 \%)$ of the publications were published by the Journal of Business Ethics. The journal Business Ethics Quarterly is secondary with six (5.77\%) publications. Third are the book "Corporate Citizenship: A Practical Guide to Delivering Value to Society and Your Business" with five (4.81\%), the Academy of Management Review with five $(4.81 \%)$, and the book "Political Role of Corporate Citizens: An Interdisciplinary Approach" also with five (4.81\%) publications. Then, Business Ethics: A European Review and Business and Society both share fourth place with four $(3.85 \%)$ publications each. The remaining 53 publications are divided into various publication forms, mainly journals, each represented by one publication.

Table 2. Top 7 Sources.

\begin{tabular}{cccc}
\hline Source & Number of Publications & $\%$ & Publication Form \\
\hline Journal of Business Ethics & 22 & 21.15 & Journal \\
Business Ethics Quarterly & 6 & 5.77 & Journal \\
Corporate Citizenship: A Practical Guide to & 5 & 4.81 & Book \\
Delivering Value to Society and Your Business & 5 & 4.81 & Journal \\
Academy of Management Review & 5 & 4.81 & Book \\
Political Role of Corporate Citizens: An & 4 & 3.85 & Journal \\
Interdisciplinary Approach & 4 & 3.85 & Journal \\
Business Ethics: A European Review & & & \\
Business and Society & &
\end{tabular}

\subsection{Journal Impact Factors}

The ten highest ranking journals that have published on corporate citizenship have impact factors between 5.51 and 41.06 (Table 3). The average impact factor of all 47 journals is 4.193 . Only three journals have impact factors below 1.00. The JIFs refer to the year 2018 and were collected from the InCites Journal Citation Reports by Clarivate Analytics. Three journals without a JIF were excluded from the list. 
Table 3. Journal Impact Factors.

\begin{tabular}{|c|c|c|}
\hline Journal & IF & Number of Publications \\
\hline Science & 41,063 & 1 \\
\hline Academy of Management Review & 10,632 & 5 \\
\hline Journal of the Academy of Marketing Science & 9360 & 1 \\
\hline Journal of International Business Studies & 7724 & 1 \\
\hline Canadian Medical Association Journal & 6938 & 1 \\
\hline Personnel Psychology & 6930 & 1 \\
\hline Journal of Cleaner Production & 6395 & 2 \\
\hline Journal of World Business & 5789 & 1 \\
\hline American Journal of Bioethics & 5786 & 1 \\
\hline $\begin{array}{c}\text { Corporate Social Responsibility and Environmental } \\
\text { Management }\end{array}$ & 5513 & 2 \\
\hline Business and Society & 5013 & 4 \\
\hline Harvard Law Review & 4680 & 1 \\
\hline Foreign Affairs & 4390 & 1 \\
\hline Journal of Business Research & 4028 & 1 \\
\hline International Journal of Contemporary Hospitality Management & 3957 & 1 \\
\hline Environmental Politics & 3827 & 1 \\
\hline Sustainable Development & 3821 & 1 \\
\hline Journal of Business Ethics & 3796 & 22 \\
\hline Long Range Planning & 3363 & 1 \\
\hline Biosocieties & 2958 & 1 \\
\hline Business Ethics-A European Review & 2919 & 4 \\
\hline Business Horizons & 2828 & 2 \\
\hline Business Ethics Quarterly & 2788 & 6 \\
\hline British Journal of Management & 2750 & 1 \\
\hline Environment and Planning D Society and Space & 2730 & 1 \\
\hline European Journal of Work and Organizational Psychology & 2598 & 1 \\
\hline Journal of Public Policy and Marketing & 2457 & 1 \\
\hline Review of Managerial Science & 2393 & 1 \\
\hline Journal of Marketing Management & 2392 & 1 \\
\hline Ethics and Information Technology & 2340 & 1 \\
\hline Journal of Occupational and Organizational Psychology & 2323 & 1 \\
\hline International Journal of Tourism Research & 2278 & 1 \\
\hline Management Decision & 1963 & 1 \\
\hline Journal of Health Politics Policy and Law & 1839 & 1 \\
\hline Sustainability Accounting Management and Policy Journal & 1745 & 1 \\
\hline Kyklos & 1674 & 1 \\
\hline Public Relations Review & 1616 & 1 \\
\hline Journal of Applied Social Psychology & 1553 & 1 \\
\hline American Historical Review & 1456 & 1 \\
\hline Scandinavian Journal of Management & 1415 & 1 \\
\hline Welding Journal & 1340 & 1 \\
\hline Journal of Urban Affairs & 1115 & 1 \\
\hline Human Performance & 1098 & 2 \\
\hline Revista de Cercetare si Interventie Sociala & 1076 & 1 \\
\hline Crime Law and Social Change & 0.952 & 1 \\
\hline American Business Law Journal & 0.786 & 2 \\
\hline European Business Organization Law Review & 0.673 & 1 \\
\hline
\end{tabular}

Three articles are both among the ten most cited papers as well as among the journals with the ten highest influencing factors. Interestingly, the article "Molecular Biology: Corporate Citizenship and Potential Profit" by Bazell [78], which appeared in Science (IF = 41.06), is only the 80th out of 104 of the most cited publications. 


\subsection{Author Productivity and Citation Analysis}

The most cited authors for this data set can be seen in Table 4. Some of the authors listed published all their publications appearing in the data set, which explains the equality of the number of publications and citation numbers.

Table 4. Top 20 Authors by citations and publications.

\begin{tabular}{ccc}
\hline Autor & Citations & Publications \\
\hline Crane, A. & 1110 & 4 \\
Matten, D. & 1110 & 4 \\
Ferrell, O.C. & 625 & 2 \\
Maignan, I. & 625 & 2 \\
Hult, G.T.M. & 476 & 1 \\
Fombrun, C.J. & 280 & 1 \\
Gardberg, N.A. & 280 & 1 \\
Lin, C.-P. & 243 & 7 \\
Chapple, W. & 202 & 1 \\
Moon, J. & 186 & 1 \\
Tsai, Y.-H. & 150 & 4 \\
Beckmann, M. & 137 & 3 \\
Hielscher, S. & 137 & 3 \\
Pies, I. & 137 & 3 \\
Chiu, C.-K. & 130 & 3 \\
Capriotti, P. & 121 & 1 \\
Moreno, A. & 121 & 1 \\
Davis, W. & 117 & 4 \\
Evans, W.R. & 117 & 4 \\
Haugh, H. & 86 & 1 \\
Phillips, N. & 86 & 1 \\
Tracey, P. & 86 & 1 \\
\hline & &
\end{tabular}

The most productive authors come primarily from the USA, followed by England, Germany, Taiwan, and Canada (Table 5).

Table 5. Top 5 Countries.

\begin{tabular}{ccc}
\hline Country & Number of Publications & In $\%$ \\
\hline USA & 32 & 30.77 \\
England & 16 & 15.39 \\
Germany & 11 & 10.58 \\
Taiwan & 9 & 8.65 \\
Canada & 5 & 4.81 \\
\hline
\end{tabular}

\subsection{Co-Author Analysis}

The entire data set contains 143 authors. This results in an average number of authors of approximately 1.4 per publication. A closer look at the number of publishers per document shows that $50.96 \%$ of the publications have one author, $26.92 \%$ two, $12.50 \%$ three, and $4.81 \%$ four or five authors.

Figure 3 shows the co-author network. There are 79 clusters, the largest of which consists of ten authors. The clusters are not interconnected, which means that relatively few authors work together to create publications, and when they do, they often collaborate with the same people multiple times. 


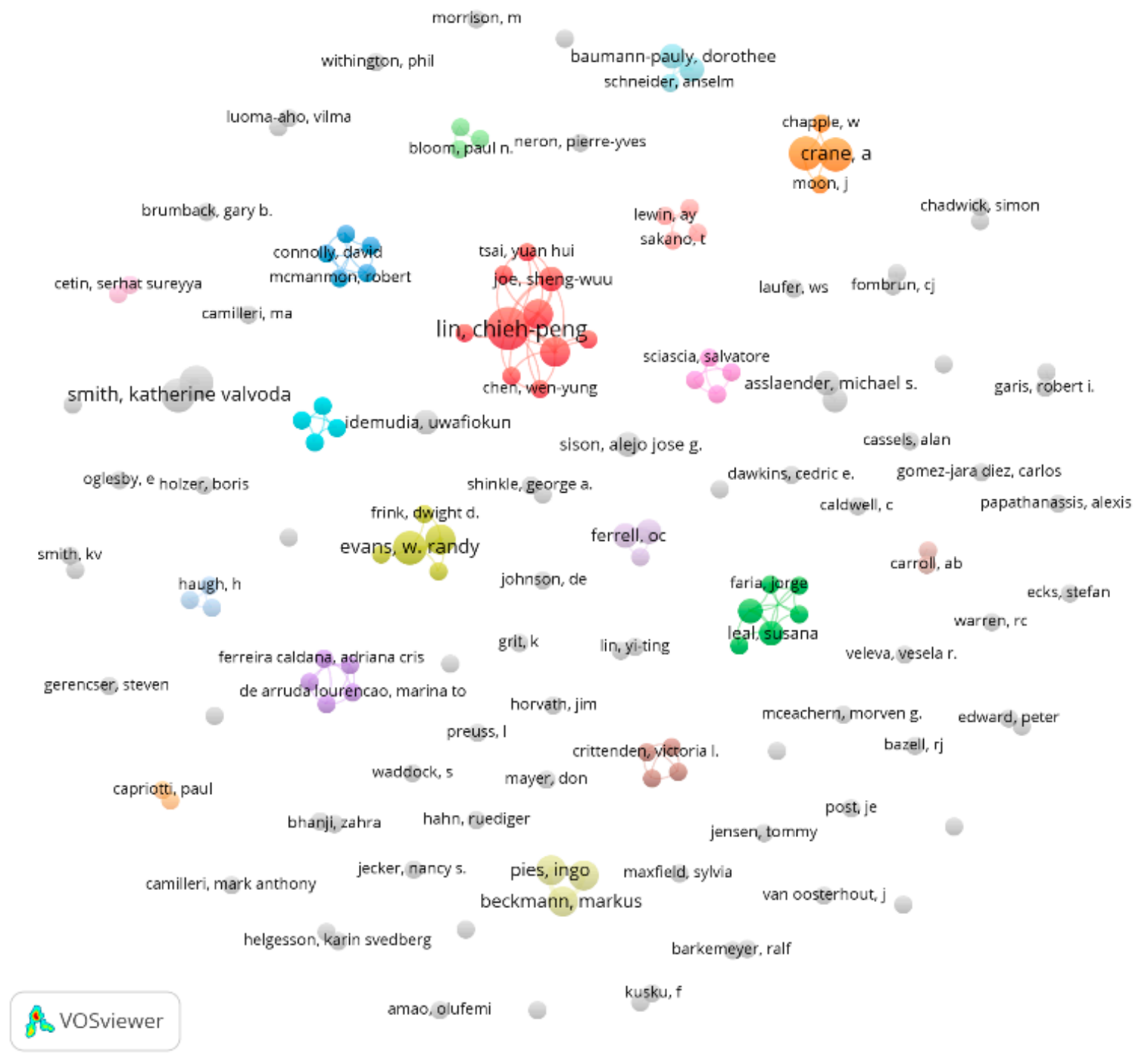

Figure 3. Co-author network.

\subsection{Article Citation Analysis}

The publications in the data set were cited 3,923 times. On average, each document was cited 37.72 times. However, the ten most cited papers already contain 2,368 citations (60.36\%). Table 6 depicts the top 20 publications by average citation per year. Nine of them were published in the Journal of Business Ethics. 
Table 6. Most cited publications by average citation per year.

\begin{tabular}{|c|c|c|c|c|c|c|}
\hline Rank & Title & Authors & Source & Year & Overall Citations & Average Citations per Year \\
\hline 1 & $\begin{array}{l}\text { Corporate citizenship: Toward an extended } \\
\text { theoretical conceptualization }\end{array}$ & Matten and Crane & $\begin{array}{c}\text { Academy of } \\
\text { Management Review }\end{array}$ & 2005 & 704 & 46.93 \\
\hline 2 & $\begin{array}{l}\text { Corporate citizenship: Cultural antecedents } \\
\text { and business benefits }\end{array}$ & Maignan et al. & $\begin{array}{l}\text { Journal of the } \\
\text { Academy of } \\
\text { Marketing Science }\end{array}$ & 1999 & 476 & 22.67 \\
\hline 3 & $\begin{array}{l}\text { Corporate citizenship: Creating intangible } \\
\text { assets across institutional environments }\end{array}$ & $\begin{array}{l}\text { Gardberg and } \\
\text { Fombrun }\end{array}$ & $\begin{array}{c}\text { Academy of } \\
\text { Management Review }\end{array}$ & 2006 & 280 & 20 \\
\hline 4 & $\begin{array}{c}\text { Can corporations be citizens? Corporate } \\
\text { citizenship as a metaphor for business } \\
\text { participation in society }\end{array}$ & Moon et al. & $\begin{array}{l}\text { Business Ethics } \\
\text { Quarterly }\end{array}$ & 2005 & 186 & 12.4 \\
\hline 5 & $\begin{array}{l}\text { Behind the mask: Revealing the true face of } \\
\text { corporate citizenship }\end{array}$ & Matten et al. & $\begin{array}{l}\text { Journal of Business } \\
\text { Ethics }\end{array}$ & 2003 & 202 & 11.88 \\
\hline 6 & $\begin{array}{l}\text { Corporate citizenship and public relations: } \\
\text { The importance and interactivity of social } \\
\text { responsibility issues on corporate websites }\end{array}$ & Capriotti and Moreno & $\begin{array}{l}\text { Public Relations } \\
\text { Review }\end{array}$ & 2007 & 121 & 9.31 \\
\hline 7 & $\begin{array}{l}\text { Modeling corporate citizenship and its } \\
\text { relationship with organizational citizenship } \\
\text { behaviors }\end{array}$ & Lin et al. & $\begin{array}{l}\text { Journal of Business } \\
\text { Ethics }\end{array}$ & 2010 & 83 & 8.3 \\
\hline 8 & $\begin{array}{c}\text { Antecedents and benefits of corporate } \\
\text { citizenship: an investigation of French } \\
\text { businesses }\end{array}$ & Maignan and Ferrell & $\begin{array}{l}\text { Journal of Business } \\
\text { Research }\end{array}$ & 2001 & 149 & 7.84 \\
\hline 9 & $\begin{array}{l}\text { Modeling corporate citizenship, } \\
\text { organizational trust, and work engagement } \\
\text { based on attachment theory }\end{array}$ & Lin & $\begin{array}{l}\text { Journal of Business } \\
\text { Ethics }\end{array}$ & 2010 & 78 & 7.8 \\
\hline 10 & $\begin{array}{l}\text { The ethical rational of business for the } \\
\text { poor-Integrating the concepts bottom of the } \\
\text { pyramid, sustainable development, and } \\
\text { corporate citizenship }\end{array}$ & Hahn & $\begin{array}{l}\text { Journal of Business } \\
\text { Ethics }\end{array}$ & 2009 & 70 & 6.36 \\
\hline 11 & $\begin{array}{l}\text { Moral commitments and the societal role of } \\
\text { business: An ordonomic approach to } \\
\text { corporate citizenship }\end{array}$ & Pies et al. & $\begin{array}{l}\text { Business Ethics } \\
\text { Quarterly }\end{array}$ & 2009 & 69 & 6.27 \\
\hline
\end{tabular}


Table 6. Cont

\begin{tabular}{|c|c|c|c|c|c|c|}
\hline Rank & Title & Authors & Source & Year & Overall Citations & Average Citations per Year \\
\hline 12 & $\begin{array}{l}\text { Beyond philanthropy: Community } \\
\text { enterprise as a basis for corporate } \\
\text { citizenship }\end{array}$ & Tracey et al. & $\begin{array}{l}\text { Journal of Business } \\
\text { Ethics }\end{array}$ & 2005 & 86 & 5.73 \\
\hline 13 & $\begin{array}{c}\text { Democratizing corporate governance: } \\
\text { Compensating for the democratic deficit of } \\
\text { corporate political activity and corporate } \\
\text { citizenship }\end{array}$ & Scherer et al. & Business and Society & 2013 & 40 & 5.71 \\
\hline 14 & $\begin{array}{l}\text { Creating corporate accountability: } \\
\text { Foundational principles to make corporate } \\
\text { citizenship real }\end{array}$ & Waddock & $\begin{array}{l}\text { Journal of Business } \\
\text { Ethics }\end{array}$ & 2004 & 81 & 5.06 \\
\hline 5 & $\begin{array}{l}\text { An examination of perceived corporate } \\
\text { citizenship, job applicant attraction, and } \\
\text { CSR work role definition }\end{array}$ & Evans et al. & Business and Society & 2011 & 46 & 5.11 \\
\hline 16 & $\begin{array}{l}\text { How the perceptions of five dimensions of } \\
\text { corporate citizenship and their } \\
\text { inter-inconsistencies predict affective } \\
\text { commitment }\end{array}$ & Rego et al. & $\begin{array}{l}\text { Journal of Business } \\
\text { Ethics }\end{array}$ & 2010 & 51 & 5.1 \\
\hline 17 & $\begin{array}{l}\text { Modeling the relationship among perceived } \\
\text { corporate citizenship, firms' attractiveness, } \\
\text { and career success expectation }\end{array}$ & Lin et al. & $\begin{array}{l}\text { Journal of Business } \\
\text { Ethics }\end{array}$ & 2012 & 39 & 4.88 \\
\hline 18 & $\begin{array}{l}\text { Global corporate citizenship-Working with } \\
\text { governments and civil society }\end{array}$ & Schwab & Foreign Affairs & 2008 & 54 & 4.5 \\
\hline 19 & $\begin{array}{l}\text { Value creation, management competencies, } \\
\text { and global corporate citizenship: An } \\
\text { ordonomic approach to business ethics in } \\
\text { the age of globalization }\end{array}$ & Pies et al. & $\begin{array}{l}\text { Journal of Business } \\
\text { Ethics }\end{array}$ & 2010 & 45 & 4.5 \\
\hline 20 & $\begin{array}{l}\text { Do ethical and sustainable practices matter? } \\
\text { Effects of corporate citizenship on business } \\
\text { performance in the hospitality industry }\end{array}$ & Wang & $\begin{array}{l}\text { International Journal } \\
\text { of Contemporary } \\
\text { Hospitality }\end{array}$ & 2014 & 27 & 4.5 \\
\hline
\end{tabular}




\subsection{Article Co-Citation Analysis}

The co-citation analysis shown in Figure 4 only includes publications that have been cited at least twice (68 publications) in order to skip the less influential publications for better clarity. The analysis resulted in 454 items, grouped in seven clusters. Due to the limited space, not all items are visible. The items include not only the 68 corporate citizenship publications from our data set, but also other publications, such as Wood [79], which are cited together with them. Items that are close to each other have a comparatively high common citation rate [40], which suggests a certain proximity of content. The graphic representation shows a tightly packed picture of co-citations. Some circles, which are represented as one item here, actually consist of more than 20 items in the original presentation). The seven clusters are not strictly distinct from each other but mostly interrelated. The size of the circles represents the total link strength, which indicates how many links each item has. The individual circles are color-coded according to publications. The highest values are shown by Carroll [80] with 712, Maignan [81] with 551, Wood [79] with 544, and Matten [37] with 532 citations. Except for the latter publication, none of these publications are part of the original data set. Accordingly, the publication with the highest number of citations has only the fourth highest weighting and thus the fourth highest value.

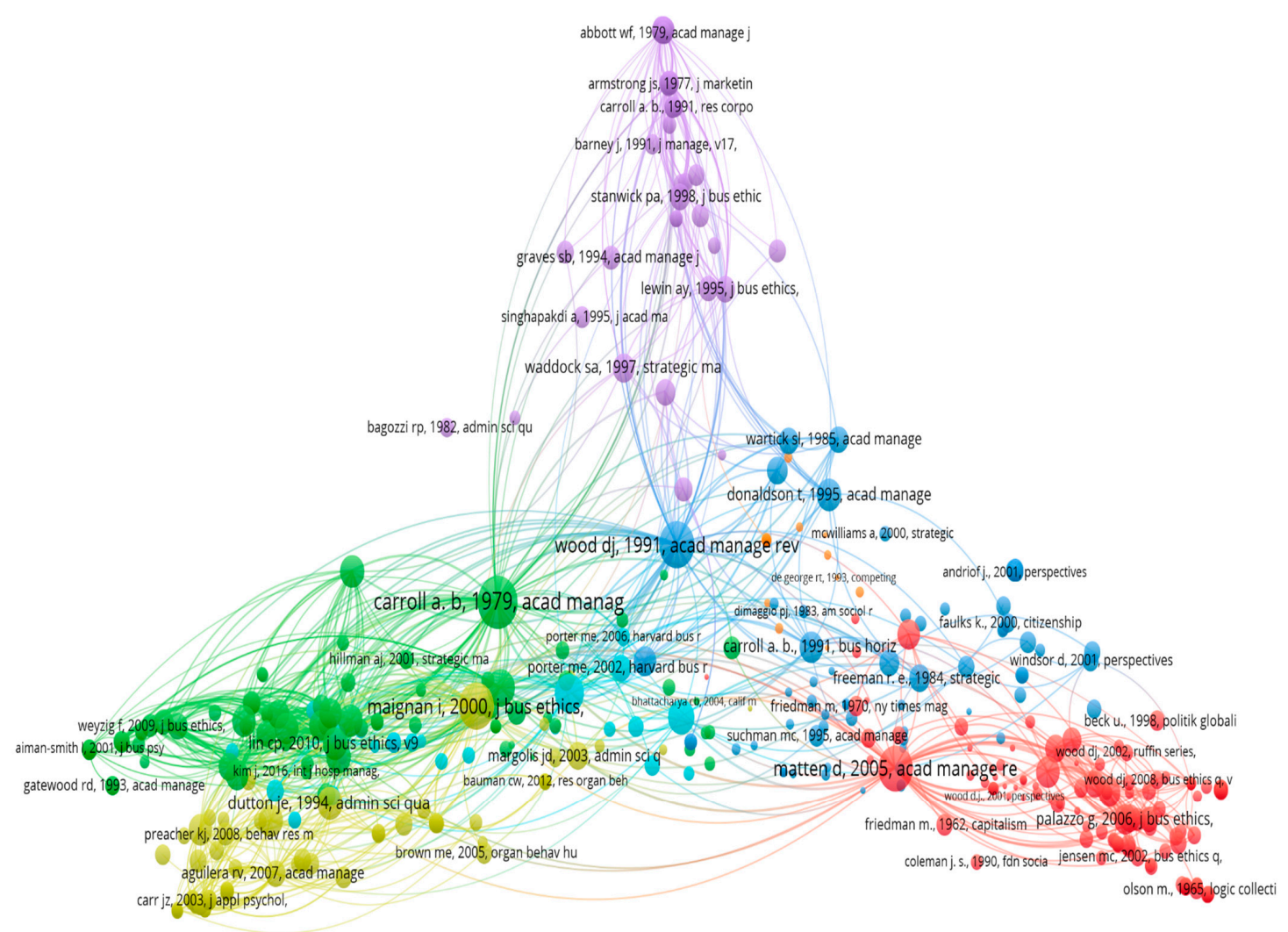

禹 vosviewer

Figure 4. Co-citation network.

\subsection{Keyword Co-Occurrence Analysis}

The co-occurrence analysis of the author keywords shows a field of 136 items in 21 clusters (Figure 5). Of these items, 130 appear once or twice in the data set. Nearby items are often mentioned together. The size of the items is determined by their weighting, namely the total number of entries. 


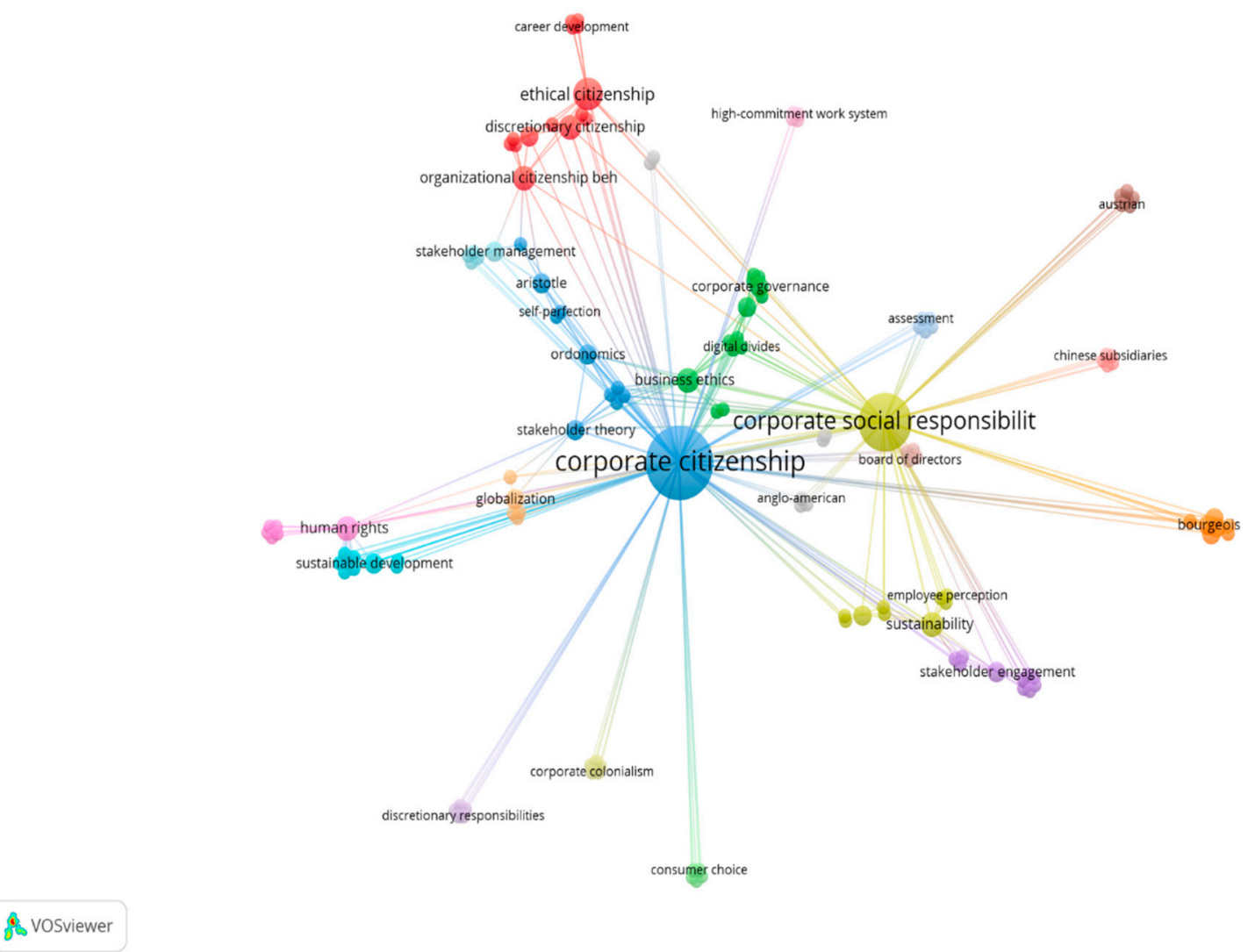

Figure 5. Keyword co-occurrence-network.

The six items that were given three or more times as keywords are: "Corporate Citizenship" with 26, "Corporate Social Responsibility" with 16, "Ethical Citizenship" with five and "Discretionary Citizenship", "Organizational Citizenship Behavior", and "Human Rights" with three uses each. The terms "Corporate Citizenship" and "Corporate Social Responsibility" are used by many authors and thus show the highest link strength in the data set. The general diversity of the clusters makes it difficult to provide them with a general term. Dark red is the largest cluster with 14 items, followed by dark green (13), dark blue (11), and yellow (10). Seven of the clusters on display consist of five items. In Figure 5, the total number of occurrences of an item was chosen as a measure of its weighting. Accordingly, the terms "Corporate Citizenship" and "Corporate Social Responsibility" represent the keywords most frequently used by the authors. They are used by many authors together and therefore have a high link strength between them. The connection strength across all key words (total link strength) is by far the highest in these two terms. Of these items, 130 appear once or twice in the local data set. The distances between clusters are mixed. The dark blue and yellow clusters represent core clusters, not least because of the main keywords "Corporate Citizenship" and "Corporate Social Responsibility". The dark green cluster lies between these terms but shows a much more common connection with the dark blue. The dark red cluster behaves in a similar way, except it is significantly further away from the yellow than the green cluster. The turquoise cluster is also completely separate from the yellow one. All in all, the dark blue cluster, in particular "Corporate Citizenship" as the term, is the center of the figure. Nevertheless, "Corporate Social Responsibility" from the dark yellow cluster also shows connections (for example, with the brown cluster) that are completely unaffected by dark blue. All in all, it is noticeable that terms related to ethics (e.g., "Ethical Citizenship" [dark red], "Business Ethics" [dark green], "Ordnonomics" [dark blue] and "Ethics" [dark yellow]) and responsibility (e.g., "Discretionary Responsibilities" [light purple], "Social" and "Environmental Responsibilities" [dark purple]) have a strong presence. 


\section{Discussion}

From the results of the bibliometric analysis, several conclusions can be drawn. In a temporal perspective, corporate citizenship was first mentioned in 1969, but serious scholarly discourse started to gain momentum in 2004. A reason for the increased interest could be corporate scandals like Enron (2001) or WorldCom (2002). Taking up a stronger ethical focus on the responsibility of corporations and the duration of the research, review, and revision processes might have caused this delay. Even though the annual number of publications since 2004 varies, we see a sharp increase in annual citations until around 2014, with subsequently stagnating citation rates. This could be interpreted as a phase of saturation. It remains to be seen if the last five years represent only an interim phase of consolidation to be followed by further growth or if the research field is in decline. Scholars who aim at high citation rates might tend to focus on the CSR concept in the future. Due to general unpredictability [82] and especially due to the current COVID-19 economic crisis [77], it is rather unclear how corporate citizenship and CSR in practice and research will further continue quantitatively. Two scenarios [83] seem feasible: firms might be forced to cut costs and reduce their social engagement, or we might see stronger societal cohesion and solidarity between citizens and firms, which might result in decreasing or increasing research efforts.

Analysis of disciplines that are involved in corporate citizenship research unsurprisingly shows that the topic is well-established in both business/management and ethics. However, political science and environmental studies also contribute to the field, showing interdisciplinarity. As corporate citizenship is an approach firms can follow voluntarily without any legal obligation, politics might discuss this conceptual split between law and ethics in order to increase firms' engagement. The involvement of environmental studies shows that corporate citizenship might be extended to the triple bottom line conceptualization [84] in which, apart from economical, not only social but also environmental issues are represented.

Analysis of the productivity of publication forms showed a clear dominance of business ethics journals, with the Journal of Business Ethics as the flagship publisher. Not surprisingly, corporate citizenship is therefore clearly a business ethics topic. However, the fact that leading journals such as the Academy of Management Review also deal with corporate citizenship shows that it is no niche topic but one that is relevant for the broad scope of business and management research. This is also underlined by the fact that 50 papers were published in highly relevant journals with an impact factor above 3 . The average impact factor is 4.08 , which can be considered quite high in business and management. Interestingly, corporate citizenship is no predominant topic in marketing journals. Therefore, it can be concluded, at least from a scholarly view, that corporate citizenship is not seen as a measure of mere "greenwashing" [85].

The analysis of co-author productivity shows that a paper has 1.4 authors on average, which is surprisingly low, considering the average number of authors in business and management being clearly above $2[86,87]$. Collaborations between co-authors tend to persist, whereas collaborations beyond these small teams hardly exist. A reason for that might be that most papers are conceptual and do not involve complex research designs, which are often related to a higher number of co-authors [88]. Corporate citizenship research also does not require interdisciplinary collaboration which would possibly increase the number of co-authors [89]. A practice of questionable co-authorships such as honorary authorships [90] can probably be precluded for the corporate citizenship field, showing that ethics researchers also behave ethically. Additionally, publish-or-perish pressure also seems to be lower compared to other fields. However, the low average number of co-authors might have a negative effect on the impact of corporate citizenship research, especially when it is measured in citations [91]. This can also be concluded from the data set as, on average, single-authored papers have smaller citation numbers than multi-authored ones. Among the 40 least-cited publications, 28 (70\%) are written by one author. In contrast, most of the highly cited papers were co-authored.

The publications are geographically divided into the United States, followed by Europe and Asia. This coincides with the results on CSR bibliometrics from Welford [92]. 
The article citation analysis shows a Pareto-like distribution. A Pareto distribution is a power-law probability distribution originally applied to describe how wealth is distributed in a society, namely that a small proportion of the population holds a large portion of wealth. Such an uneven distribution also applies to citations, where a small number of papers accounts for the multitude of all citations in the field, whereas the majority of papers received only a few citations. Interestingly, the three papers with the highest average citations per year were not published in journals that specifically focus on business ethics but on management in general. Being published in journals with a broader scope and higher impact factor can obviously contribute to an increased attention and promotion of a research field.

The article co-citation analysis showed a strongly interconnected network and somewhat relativizes the picture of isolated research suggested by the co-author analysis. Whereas authors tend to actively collaborate with only a few colleagues, they clearly appreciate other scholars' work by citing their publications. Additionally, the analysis shows that corporate citizenship publications are often co-cited with publications from other fields, especially CSR. This, again, shows the very close relationship of both research streams.

Finally, the keyword co-occurrence analysis shows the broad scope of related topics corporate citizenship research deals with. Apart from corporate citizenship's philosophical foundations and, again, CSR, corporate citizenship research touches on other sub-fields in or related to business ethics such as corporate governance, sustainability, and human rights. However, research in the field of human resource management and organization can also be identified, as represented by keywords such as "career expectation," "organizational citizenship behavior," "organizational commitment," and "organizational trust". Apparently, most of these keywords deal with "work engagement" which itself also appears as a keyword. Corporate citizenship as a specific form of corporate, i.e., collective, behavior can be seen as an influencing factor on individual behavior. More specifically, employees who work in firms that engage in corporate citizenship are expected to show more engagement in their work. This increased commitment could even exceed formal duties, as organizational citizenship behavior research suggests [93-95]. However, the line between employees' additional well-being and firms' potential to exploit employees and therefore unethical behavior might be thin.

As in all research, our study has several limitations. First, bibliometrics depends on the completeness and quality of the data set. The choice of the database, automatic selection criteria, and manual selection of publications could lead to results that might differ from bibliometric analyses that made different choices. Second, attempts to cluster a research field might suggest a clear distinction of sub-fields. However, this impression should be avoided [74]. This is also the case in this study, where clusters appear rather fuzzy. Third, when interpreting bibliometrics, researchers should always be aware of the Matthew effect, i.e., frequently cited articles are blindly cited just because they have been cited often already [96]. For example, for an initial bust in citations, the cronyism effect, which states that scholars preferably cite work of their close colleagues [96], might be sufficient.

In order to leave the current stagnation phase, corporate citizenship researchers should expand their network of co-authors and intensify their collaboration. Additionally, in order to shift corporate citizenship from the current niche to mainstream research, it is advisable to build conceptual bridges to established topics in business and management research and to publish in major business and management journals. We can already see this happening regarding human resource management and organization studies. However, other domains also seem relevant. For example, it is somewhat surprising that corporate citizenship so far hardly addresses marketing and the right balance between "true" corporate citizenship and mere greenwashing [85].

\section{Conclusions}

Research on corporate citizenship has resulted in a rich publication landscape which tends to be complex and fragmented. In order to structure the field quantitatively, we employed bibliometric analyses. Specifically, we conducted a temporal analysis of publications and citations, an analysis of 
the productivity of involved disciplines, an analysis of the productivity of publication forms including journal impact factors, an author productivity and citation analysis, a co-author analysis, an article citation analysis, an article co-citation analysis, and a keyword co-occurrence analysis.

Our results show that first publications go back to 1969, and research gained momentum in 2004, with a volatile number of annual publications since then. Citations started to rapidly grow in 2007 and have so far reached a plateau since 2014. Therefore, it is unclear if corporate citizenship will leave its current phase of stagnation and will decline or gain momentum again.

Corporate citizenship as a business ethics topic is at the intersection of business/management and ethics. However, political and environmental sciences also conduct research on the concept, showing some interdisciplinarity in the subject.

Publishing about corporate citizenship takes place predominantly in journals, with the Journal of Business Ethics as its main outlet. In general, scholars publish in journals with an average impact factor of more than 4, showing that corporate citizenship research is being published in highly relevant journals.

Authors show a rather low collaboration rate. On average, only 1.4 co-authors publish papers on corporate citizenship, and co-author teams hardly change. This lack of networking impedes the further progress and impact of the research field.

Citations are highly unevenly distributed, showing a Pareto-like distribution, i.e., a small number of publications account for a large share of all citations. The highest citation rates could be achieved by papers published in journals with broader management rather than a more specific scope.

The co-citation analysis relativizes the picture of isolated scholarly work on corporate citizenship. Despite collaborating only to a small extent, authors appreciate other authors' work and cite their publications. Corporate citizenship publications are often co-cited with CSR publications, which suggests a close proximity between both research fields.

Authors use a multitude of keywords to describe focal points in their research. Philosophical foundations and relations to CSR research, as well as to other business ethic topics, are clearly visible. However, connections to human resource management and organization studies can also be identified, especially regarding the influence of corporate citizenship on work engagement.

Author Contributions: Conceptualization, A.K. and V.T.; methodology, A.K. and V.T.; software, A.K.; formal analysis, A.K.; investigation, A.K., V.T., and M.F.; data curation, A.K.; writing-original draft preparation, A.K., V.T., and M.F.; writing-review and editing, V.T. and M.F.; visualization, A.K.; funding acquisition, V.T. All authors have read and agreed to the published version of the manuscript.

Funding: We acknowledge the support of the Deutsche Forschungsgemeinschaft and Open Access Publishing Fund of University of Potsdam.

Conflicts of Interest: The authors declare no conflict of interest.

\section{References}

1. Hackett, J.T. Corporate citizenship-Resolution of a dilemma. Bus. Horiz. 1969, 12, 69-79. [CrossRef]

2. Coldwell, C. Examining corporate citizenship: Balancing duties and opportunities in the modern organization. Bus. Ethics Q. 2004, 14, 775-780. [CrossRef]

3. Grit, K. Corporate citizenship: How to strengthen the social responsibility of managers? J. Bus. Ethics 2004, 53, 97-106. [CrossRef]

4. Harvard Law Review Finding strategic corporate citizenship: A new game theoretic view. Harv. Law Rev. 2004, 117, 1957-1980. [CrossRef]

5. Jeurissen, R. Institutional conditions of corporate citizenship. J. Bus. Ethics 2004, 53, 87-96. [CrossRef]

6. Kusku, F.; Zarkada-Fraser, A. An empirical investigation of corporate citizenship in Australia and Turkey. Br. J. Manag. 2004, 15, 57-72. [CrossRef]

7. Morrison, M. The civil corporation: The new economy of corporate citizenship. Environ. Politics 2004, 13, 672-673.

8. Oglesby, E. Corporate citizenship? Elites, labor, and the geographies of work in Guatemala. Environ. Plan. D Soc. Space 2004, 22, 553-572. [CrossRef] 
9. Waddock, S. Creating corporate accountability: Foundational principles to make corporate citizenship real. J. Bus. Ethics 2004, 50, 313-327. [CrossRef]

10. Habisch, A.; Neureiter, M.; Schmidpeter, R. Handbuch Corporate Citizenship: Corporate Social Responsibility für Manager; Springer-Verlag: Berlin/Heidelberg, Germany, 2008.

11. Altman, B.W.; Vidaver-Cohen, D. A Framework for Understanding Corporate Citizenship. Bus. Soc. Rev. 2000, 105, 1-7. [CrossRef]

12. Carrol, A.B. The four faces of corporate citizenship. Bus. Soc. Rev. 1998, 100, 1-7. [CrossRef]

13. Latapí Agudelo, M.A.; Jóhannsdottir, L.; Davídsdóttir, B. A literature review of the history and evolution of corporate social responsibility. Int. J. Corp. Soc. Responsib. 2019, 4, 1. [CrossRef]

14. Tranfield, D.; Denyer, D.; Smart, P. Towards a Methodology for Developing Evidence-Informed Management Knowledge by Means of Systematic Review. Br. J. Manag. 2003, 14, 207-222. [CrossRef]

15. Ball, R.; Tunger, D. Bibliometrische Analysen-Daten, Fakten und Methoden: Grundwissen Bibliometrie für Wissenschaftler, Wissenschaftsmanager, Forschungseinrichtungen und Hochschulen; Forschungszentrum, Zentralbibliothek: Jülich, Germany, 2005.

16. Matten, D.; Crane, A.; Chapple, W. Behind the Mask: Revealing the True Face of Corporate Citizenship. J. Bus. Ethics 2003, 45, 109-120. [CrossRef]

17. Abad-Segura, E.; Cortes-Garcia, F.J.; Belmonte-Urena, L.J. The Sustainable Approach to Corporate Social Responsibility: A Global Analysis and Future Trends. Sustainability 2019, 11, 5382. [CrossRef]

18. Alfakhri, Y.; Nurunnabi, M.; Alfakhri, D. A citation analysis of corporate social responsibility (1970-2014): Insights from Islamic perspective. J. Islamic Mark. 2018, 9, 621-654. [CrossRef]

19. Bakker, F.G.A.; de Groenewegen, P.; Den Hond, F. A Bibliometric Analysis of 30 Years of Research and Theory on Corporate Social Responsibility and Corporate Social Performance. Bus. Soc. 2005, 44, 283-317. [CrossRef]

20. Bhattacharyya, S.S.; Verma, S. The intellectual contours of corporate social responsibility literature Co-citation analysis study. Int. J. Sociol. Social Policy 2020, in press. [CrossRef]

21. Feng, Y.; Zhu, Q.; Lai, K.-H. Corporate social responsibility for supply chain management: A literature review and bibliometric analysis. J. Clean. Prod. 2017, 158, 296-307. [CrossRef]

22. Ferramosca, S.; Verona, R. Framing the evolution of corporate social responsibility as a discipline (1973-2018): A large-scale scientometric analysis. Corp. Soc. Responsib. Environ. Manag. 2020, 27, 178-203. [CrossRef]

23. Zhao, H.; Zhang, F.; Kwon, J. Corporate social responsibility research in international business journals: An author co-citation analysis. Int. Bus. Rev. 2018, 27, 389-400. [CrossRef]

24. Chakraborty, A.; Jha, A. Corporate social responsibility in marketing: A review of the state-of-the-art literature. J. Soc. Mark. 2019, 9, 418-446. [CrossRef]

25. De Stefano, F.; Bagdadli, S.; Camuffo, A. The HR role in corporate social responsibility and sustainability: A boundary-shifting literature review. Hum. Resour. Manag. 2017, 57, 549-566. [CrossRef]

26. Sharma, E. A review of corporate social responsibility in developed and developing nations. Corp. Soc. Responsib. Environ. Manag. 2019, 26, 712-720.

27. Palakshappa, N.; Grant, S. Social enterprise and corporate social responsibility: Toward a deeper understanding of the links and overlaps. Int. J. Entrep. Behav. Res. 2018, 24, 606-625. [CrossRef]

28. Van Oosterhout, J.H. Corporate Citizenship: An Idea Whose Time Has Not Yet Come. Acad. Manag. Rev. 2005, 30, 677-681. [CrossRef]

29. Aßländer, M.S.; Curbach, J. The Corporation as Citoyen? Towards a New Understanding of Corporate Citizenship. J. Bus. Ethics 2014, 120, 541-554. [CrossRef]

30. Camilleri, M.A. Corporate Citizenship and social responsibility in the United States of America. Sustain. Account. Manag. Policy J. 2017, 8, 77-93. [CrossRef]

31. Van Luijk, H.J.L. Business Ethics in Europe: A Tale of Two Efforts. In Wirtschaftsethik in Mittel- und Osteuropa; Lang, R., Ed.; Rainer Hampp: München, Germany, 2001; pp. 9-18.

32. Leisinger, K.M. Corporate Philanthropy: The "Top of the Pyramid". Bus. Soc. Rev. 2007, 112, 315-342. [CrossRef]

33. Van Oosterhout, J.H. Transcending the Confines of Economic and Political Organization? The Misguided Metaphor of Corporate Citizenship. Bus. Ethics Q. 2008, 18, 35-42. [CrossRef] 
34. Homburg, C.; Stierl, M.; Bornemann, T. Corporate social responsibility in business-to-business markets: How organizational customers account for supplier corporate social responsibility engagement. J. Mark. 2013, 77, 54-72. [CrossRef]

35. Dežmar-Krainz, K. Enhancing wellbeing of employees through corporate social responsibility context. Megatrend Rev. 2015, 12, 137-153. [CrossRef]

36. Popescu, C.R.G.H. "Intellectual Capital”: Major Role, Key Importance and Decisive Influences on Organizations' Performance. J. Hum. Resour. Manag. Res. 2019, 2019, 509857.

37. Crane, A.; Matten, D. Corporate Citizenship: Missing the Point or Missing the Boat? A Reply To Van Oosterhout. Acad. Manag. Rev. 2005, 30, 681-684. [CrossRef]

38. Sison, A.J.G. From CSR to Corporate Citizenship: Anglo-American and Continental European Perspectives. J. Bus. Ethics 2009, 89, 235-246. [CrossRef]

39. Diodato, V.P.; Gellatly, P. Dictionary of Bibliometrics; Taylor and Francis: Hoboken, NJ, USA, 2013.

40. Kücher, A.; Feldbauer-Durstmüller, B. Organizational failure and decline-A bibliometric study of the scientific frontend. J. Bus. Res. 2019, 98, 503-516. [CrossRef]

41. Luther, L.; Tiberius, V.; Brem, A. User Experience (UX) in business, management, and psychology: A bibliometric mapping of the current state of research. Multimodal Technol. Interact. 2020, 4, 18. [CrossRef]

42. Pritchard, A. Statistical bibliography or bibliometrics? J. Doc. 1969, 25, 348-349.

43. Zupic, I.; Čater, T. Bibliometric Methods in Management and Organization. Organ. Res. Methods 2015, 18, 429-472. [CrossRef]

44. Culnan, M.J. Mapping the Intellectual Structure of MIS, 1980-1985: A Co-Citation Analysis. Mis Q. 1987, 11, 341-353. [CrossRef]

45. Culnan, M.J.; O’Reilly, C.A., III.; Chatman, J.A. Intellectual structure of research in organizational behavior, 1972-1984: A cocitation analysis. J. Am. Soc. Inf. Sci. 1990, 41, 453-458. [CrossRef]

46. Devos, P. Research and bibliometrics: A long history ... . Clin. Res. Hepatol. Gastroenterol. 2011, 35, $336-337$. [CrossRef] [PubMed]

47. Gundolf, K.; Filser, M. Management Research and Religion: A Citation Analysis. J. Bus. Ethics 2013, 112, 177-185. [CrossRef]

48. Yue, W.; Wilson, C.S. Measuring the citation impact of research journals in clinical neurology: A structural equation modelling analysis. Scientometrics 2004, 60, 317-332. [CrossRef]

49. Calabretta, G.; Durisin, B.; Ogliengo, M. Uncovering the Intellectual Structure of Research in Business Ethics: A Journey through the History, the Classics, and the Pillars of Journal of Business Ethics. J. Bus. Ethics 2011, 104, 499-524. [CrossRef]

50. Dreesbach-Bundy, S.; Scheck, B. Corporate volunteering: A bibliometric analysis from 1990 to 2015. Bus. Ethics A Eur. Rev. 2017, 26, 240-256. [CrossRef]

51. Koseoglu, M.A.; Sehitoglu, Y.; Ross, G.; Parnell, J.A. The evolution of business ethics research in the realm of tourism and hospitality A bibliometric analysis. Int. J. Contemp. Hosp. Manag. 2016, 28, 1598-1621. [CrossRef]

52. Koseoglu, M.A.; Yildiz, M.; Ciftci, T. Authorship trends and collaboration patterns in business ethics literature. Bus. Ethics A Eur. Rev. 2018, 27, 164-177. [CrossRef]

53. Leiva, R.; Ferrero, I.; Calderon, R. Corporate Reputation in the Business Ethics Field: Its Relation with Corporate Identity, Corporate Image, and Corporate Social Responsibility. Corp. Reput. Rev. 2016, 19, 299-315. [CrossRef]

54. Talukdar, D. Patterns of Research Productivity in the Business Ethics Literature: Insights from Analyses of Bibliometric Distributions. J. Bus. Ethics 2011, 98, 137-151. [CrossRef]

55. Uysal, O.O. Business Ethics Research with an Accounting Focus: A Bibliometric Analysis from 1988 to 2007. J. Bus. Ethics 2010, 104, 499-524.

56. Vallaster, C.; Kraus, S.; Kailer, N.; Baldwin, B. Responsible entrepreneurship: Outlining the contingencies. Int. J. Entrep. Behav. Res. 2019, 25, 538-553. [CrossRef]

57. Vallaster, C.; Kraus, S.; Lindahl, J.M.M.; Nielsen, A. Ethics and entrepreneurship: A bibliometric study and literature review. J. Bus. Res. 2019, 99, 226-237. [CrossRef]

58. Bartolacci, F.; Caputo, A.; Soverchia, M. Sustainability and financial performance of small and medium sized enterprises: A bibliometric and systematic literature review. Bus. Strategy Environ. 2019, 29, 1297-1309. [CrossRef] 
59. Cullen, J.G. Educating Business Students About Sustainability: A Bibliometric Review of Current Trends and Research Needs. J. Bus. Ethics 2017, 145, 429-439. [CrossRef]

60. Franceschini, S.; Faria, L.G.; Jurowetzki, R. Unveiling scientific communities about sustainability and innovation. A bibliometric journey around sustainable terms. J. Clean. Prod. 2016, 127, 72-83. [CrossRef]

61. Garrigos-Simon, F.J.; Botella-Carrubi, M.D.; Gonzalez-Cruz, T.F. Social capital, human capital, and sustainability: A bibliometric and visualization analysis. Sustainability 2018, 10, 4751. [CrossRef]

62. Garrigos-Simon, F.J.; Narangajavana-Kaosiri, Y.; Lengua-Lengua, I. Tourism and sustainability: A bibliometric and visualization analysis. Sustainability 2018, 10, 1976. [CrossRef]

63. Kitsios, F.; Kamariotou, M.; Talias, M.A. Corporate Sustainability Strategies and Decision Support Methods: A Bibliometric Analysis. Sustainability 2020, 12, 521. [CrossRef]

64. Niñerola, A.; Sánchez-Rebull, M.V.; Hernández-Lara, A.B. Tourism research on sustainability: A bibliometric analysis. Sustainability 2019, 11, 1377. [CrossRef]

65. Punnakitikashem, P.; Hallinger, P. Bibliometric Review of the Knowledge Base on Healthcare Management for Sustainability, 1994-2018. Sustainability 2020, 12, 205. [CrossRef]

66. Sanguankaew, P.; Vathanophas Ractham, V. Bibliometric review of research on knowledge management and sustainability, 1994-2018. Sustainability 2019, 11, 4388. [CrossRef]

67. Suriyankietkaew, S.; Petison, P. A Retrospective and Foresight: Bibliometric Review of International Research on Strategic Management for Sustainability, 1991-2019. Sustainability 2020, 12, 91. [CrossRef]

68. Tang, M.; Liao, H.; Wan, Z.; Herrera-Viedma, E.; Rosen, M.A. Ten years of sustainability (2009 to 2018): A bibliometric overview. Sustainability 2018, 10, 1655. [CrossRef]

69. Glänzel, W.; Schubert, A. Analyzing scientific networks through co-authorship. In Handbook of Quantitative Science and Technology Research. The Use of Publication and Patent Statistics in Studies of SET Systems; Moed, H.F., Glänzel, W., Schmoch, U., Eds.; Springer Science + Business Media Inc.: Dordrecht, Germany, 2005; pp. 257-276.

70. Vogel, R.; Güttel, W.H. The Dynamic Capability View in Strategic Management: A Bibliometric Review. Int. J. Manag. Rev. 2013, 15, 426-446. [CrossRef]

71. Small, H. Co-citation in the scientific literature: A new measure of the relationship between two documents. J. Am. Soc. Inf. Sci. 1973, 24, 265-269. [CrossRef]

72. Van Eck, N.J.; Waltman, L. VOSviewer Manual-version 1.6.10. 2019. Available online: https://www. vosviewer.com/documentation/Manual_VOSviewer_1.6.10.pdf (accessed on 16 April 2020).

73. Van Eck, N.J.; Waltman, L. Visualizing Bibliometric Networks. In Measuring Scholarly Impact; Ding, Y., Rousseau, R., Wolfram, D., Eds.; Springer International Publishing: Cham, Switzerland, 2014; pp. 285-320.

74. Waltman, L.; van Eck, N.J.; Noyons, E.C.M. A unified approach to mapping and clustering of bibliometric networks. J. Informetr. 2010, 4, 629-635. [CrossRef]

75. Gurzki, H.; Woisetschläger, D.M. Mapping the luxury research landscape: A bibliometric citation analysis. J. Bus. Res. 2017, 77, 147-166. [CrossRef]

76. Kraus, S.; Breier, M.; Dasí-Rodríguez, S. The art of crafting a systematic literature review in entrepreneurship research. Int. Entrep. Manag. J. 2020, in press. [CrossRef]

77. Kraus, S.; Clauß, T.; Breier, M.; Gast, J.; Zardini, A.; Tiberius, V. The economics of COVID-19: Initial empirical evidence on how family firms in five European countries cope with the corona crisis. Int. J. Entrep. Behav. Res. 2020, in press. [CrossRef]

78. Bazell, R.J. Molecular biology: Corporate citizenship and potential profit. Science 1971, 174, $275-276$. [CrossRef] [PubMed]

79. Wood, D.J. Corporate Social Performance Revisited. Acad. Manag. Rev. 1991, 16, 691-718. [CrossRef]

80. Carroll, A.B. A Three-Dimensional Conceptual Model of Corporate Performance. Acad. Manag. Rev. 1979, 4, 497-505. [CrossRef]

81. Maignan, I.; Ferrell, O.C.; Hult, G.T.M. Corporate Citizenship: Cultural Antecedents and Business Benefits. J. Acad. Mark. Sci. 1999, 27, 455-469. [CrossRef]

82. Tiberius, V. Theorien des Wandels—Theorien der Zukunftsgenese? In Zukunftsgenese—Theorien des zukünftigen Wandels; Tiberius, V., Ed.; VS Verlag für Sozialwissenschaften: Wiesbaden, Germany, 2012; pp. 11-54.

83. Tiberius, V. Scenarios in the strategy process: A framework of affordances and constraints. Eur. J. Futures Res. 2019, 7, 7. [CrossRef] 
84. Elkington, J. Cannibals with Forks: The Tripple Bottom Line of the 21st Century Business; New Society Publishers: Stony Creek, CT, USA, 1998.

85. Laufer, W.S. Social accountability and corporate greenwashing. J. Bus. Ethics 2003, 43, 253-261. [CrossRef]

86. Henriksen, D. The rise in co-authorship in the social sciences (1980-2013). Scientometrics 2016, 107, 455-476. [CrossRef]

87. Parish, A.J.; Boyack, K.W.; Ioannidis, J.P.A. Dynamics of co-authorship and productivity across different fields of scientific research. PLoS ONE 2018, 13, e0189742. [CrossRef]

88. Fanelli, D.; Larivière, V. Researchers' individual publication rate has not increased in a century. PLoS ONE 2016, 11, e0149504. [CrossRef]

89. Porter, A.L.; Rafols, I. Is science becoming more interdisciplinary? Measuring and mapping six research fields over time. Scientometrics 2009, 81, 719-745. [CrossRef]

90. Fong, E.A.; Wilhite, A.W. Authorship and citation manipulation in academic research. PLoS ONE 2017, 12, e0187394. [CrossRef] [PubMed]

91. Liao, C.H. How to improve research quality? Examining the impacts of collaboration intensity and member diversity in collaboration networks. Scientometrics 2011, 86, 747-761. [CrossRef]

92. Welford, R. Corporate Social Responsibility in Europe, North America and Asia: 2004 Survey Results. J. Corp. Citizsh. 2005, 17, 33-52.

93. Organ, D.W. Organizational citizenship behavior-It's construct clean-up time. Hum. Perform. 1997, 10, 85-97. [CrossRef]

94. Smith, C.A.; Organ, D.W.; Near, J.P. Organizational citizenship behavior-Its nature and antecedents. J. Appl. Psychol. 1983, 68, 653-663. [CrossRef]

95. Valeau, P.J.; Paille, P. The management of professional employees: Linking progressive HRM practices, cognitive orientations and organizational citizenship behavior. Int. J. Hum. Resour. Manag. 2019, 30, 2705-2731. [CrossRef]

96. García-Lillo, F.; Úbeda-García, M.; Marco-Lajara, B. The intellectual structure of human resource management research: A bibliometric study of the international journal of human resource management, 2000-2012. Int. J. Hum. Resour. Manag. 2017, 28, 1786-1815. [CrossRef] 